\title{
Supporting food security in the 21st century through resource-conserving increases in agricultural production
}

Norman Uphoff',2

\begin{abstract}
The Green Revolution was accomplished under a set of demographic, economic, climatic and other conditions in the 20th century that have been changing and will surely be different and more difficult in the decades ahead. The suitability and sustainability of any given agricultural technology depends on factors like resource availability and productivity, energy costs, and environmental constraints. The achievements of Green Revolution technologies in the 1960s and 1970s came at a critical time of impending food shortages, and the world's people would be worse off without them. However, the rate of yield improvement for cereal production has been slowing since the mid-1980s.

Looking ahead at the foreseeable circumstances under which 21st century agricultural producers must try to assure food security, there will be need for technologies that are less dependent on resources that are becoming relatively scarcer, like arable land and water, or becoming relatively more costly, like energy and petrochemical-based inputs. This paper considers agroecologically-based innovations that reduce farmers' dependence on external inputs, relying more on endogenous processes and existing potentials in plants and soil systems. Such resource-conserving production represents a different approach to meeting food security goals.

While these innovations are not yet fully understood and are still being researched, there are good agronomic reasons to account for their effectiveness, and scientific validations are accumulating. Enough successes have been recorded from making changes in the management of plants, soil, water and nutrients that more attention from researchers, policy-makers and practitioners is warranted, especially given the need to adapt to, and to mitigate the effects of, climate change. The same agroecological concepts and management methods that are enhancing factor productivity in rice production are giving similar results with other crops such as wheat, finger millet, sugarcane, mustard, and tef.

Genetic potentials are the starting point for any and all agricultural production, and current efforts to improve food security and nutrition through plant breeding efforts should continue. However, future research and production strategies could beneficially seek to capitalize on biological processes and potentials existing within crops and in their supporting soil systems, rather than focusing so predominantly on making modifications in genetic factors. Scientific advances in the domains of microbiology, soil ecology and epigenetics could foreseeably assist farmers in meeting production and income goals with resource-economizing methods. It remains to be seen to what extent agroecologically-informed methods can help farmers meet expected agricultural production requirements to ensure global food security, but this direction deserves more attention and support.
\end{abstract}

Keywords: Agroecology, Food security, Green revolution, Soil biota, System of rice intensification

\footnotetext{
Correspondence: ntul@cornell.edu

${ }^{1}$ SRI International Network and Resources Center (SRI-Rice), Cornell University, Ithaca, NY 14853, USA

${ }^{2}$ Cornell International Institute for Food, Agriculture and Development (CIIFAD), Cornell University, Ithaca, NY 14853, USA
}

\section{Ciomed Central}

(c) 2012 Uphoff; licensee BioMed Central Ltd. This is an Open Access article distributed under the terms of the Creative Commons Attribution License (http://creativecommons.org/licenses/by/2.0), which permits unrestricted use, distribution, and reproduction in any medium, provided the original work is properly cited. 


\section{Introduction}

An overriding challenge for agricultural research and practice in the 21st century will be to produce more food and fiber with less investment of our land, labor, capital and (particularly) water resources. This large order must be met in the context of less favorable weather conditions for much if not most of our planet, as weather shifts and variability are becoming ever-more evident constraints for agricultural scientists, policymakers, and practitioners.

Dr. Norman Borlaug and his generation of agricultural scientists gave leadership in the 20th century to meeting the challenge faced then of 'feeding a hungry planet'. Fortunately, they achieved some quick and remarkable technological advances under the banner of the Green Revolution. It does not detract from their accomplishment of raising cereal yields substantially to note, however, that these gains were made mostly in Asia, and that the opportunities were not equally distributed across all sizes of landholding. A more crucial consideration at present is that these improvements have been slackening over the past 25 years.

Without the increases in production that resulted from the Green Revolution, millions of people would have suffered from sickness and hunger, and many would have died if there had not been significant increases in food availability in the latter part of the past century. This accomplishment is evident from a 50\% decline in the relative real price of food over a four decade period.

But this favorable trend has been reversed, with food prices again rising in recent years. Moreover, we have to deal now with some very stark constraints foreseeable in this century. Many millions of agricultural producers, particularly in Africa, need to raise their production very substantially with the resources that they have at hand if life-saving levels of food security are to be achieved and maintained, to keep hunger, poverty and other woes from becoming more widespread.

\section{Reckoning with a changing world}

The world situation 50 years ago with rapid population growth presented an ominous, even dire, threat to the well-being of all people, rich and poor alike. In the 21st century, this pressure has fortunately abated as population growth rates have fallen dramatically over the last three decades. Still, the momentum of even decelerating population growth means that we must reckon with 9 to 10 billion people as the lowest peak population that can be expected in this century, and some of the poorest countries still have very rapid population growth.

It is good news that the 'population bomb' now appears unlikely to explode. A world population which stabilizes at less than 10 billion, and then possibly declines, is only half as large as what demographers were predicting when I began working on development issues over four decades ago. Deceleration of population growth, to be sure, brings some of its own challenges, as there may not be enough productive younger countrymen and women to support elderly populations. However, such problems are less difficult to cope with than the multiple 'bad news' trends that we need to grapple with now.

In this century, we face a threat to our welfare and even to our existence that is even more inexorable and potentially devastating than population growth - climate change. It is neither alarmist nor paranoid to point out that the continuation of our human species depends on remaining within the ranges of temperature, precipitation and other climate parameters within which our and other species have evolved.

While humans are unique in their ability to expand the range of environments in which they can live, drawing on our intelligence, culture and technology, the means for extension and adaptation of human habitats do not come free, and the ranges that are physiologically as well as economically tolerable are fairly narrow. There are significant economic and environmental costs as well as some social and cultural costs involved.

Agriculture as a sector is uniquely sensitive to, and dependent on, weather factors. As we think about our countries' agricultural sectors in the future, we need to figure out how we can cultivate our crops, raise our livestock, and fish our water bodies with more resourceeconomizing methods, no longer using water, metals, chemicals and fuels as profligately as in the past. Furthermore, how can we devise ways to protect our soil systems, watersheds, forests, hydrological cycles and agroecosystems - indeed, how can we restore and replenish them?

Most of the concepts, principles, laws and even methodologies in our scientific domain have been developed within the realms of chemistry, physics and engineering, where closed-system thinking is realistic, indeed necessary. Biology, on the other hand, operates with the nonlinear logic of open systems, where small inputs can produce large outputs, but also where huge inputs can give no output at all. While biology has inputs and outputs parallel to those that drive chemical and physical processes and that get channeled by engineering, its throughputs function quite differently.

When trying to understand, maintain and improve open-system phenomena, we should guard against mindsets and assumptions that were derived from, and are appropriate to, closed systems. While engineering concepts can be applied to agriculture, this does not mean that agriculture should be seen or managed simply as an industrial enterprise. Although agricultural practice has many industrial characteristics and opportunities, it 
remains essentially biological. This becomes even more evident as we gain a better understanding of some microbiological dimensions of agriculture as discussed below.

\section{When doing more of the same won't do}

The changing circumstances under which agriculture will be practiced in the 21st century are likely to make less effective and less economic the agricultural technologies that were successful in the preceding century, even with some modifications and evolutions. The foreseeable world presents us with rather different conditions and constraints than we had to deal with in the past.

As explained by Hayami and Ruttan [1], past changes in agricultural technology have been driven by changing factor proportions. These inexorably reshape and redirect our future technological paths, reflecting the relative amounts and productivities of land, labor and other resources. The added impacts now of climate change will make the need for different, even novel technological solutions even more certain.

Agriculture in the 21st century will have to deal with major alterations in the physical and institutional landscape:

- Arable land per capita is declining. While different definitions of land quality can lead to different numbers, the combination of continuing population growth and land degradation is surely lowering this ratio. By some calculations, by the middle of the 21 st century there will be about one-third as much cultivable area per person as 100 years earlier, falling from about 0.25 ha to 0.08 ha per person.

Land-extensive strategies will thus become less tenable as the ratios of population-to-land continue to change substantially [2].

- Supply of water, absolutely essential for agricultural production, is becoming less reliable as well as less available for farmers. This is a result of competing uses, of declines in water quality and of shifting weather patterns, so economizing on water is becoming an agricultural and social imperative; getting 'more crop per drop'.

- Energy costs in the 21st century will almost certainly be higher than in the 20th century, making energy-intensive production more costly. This applies to the mechanization of operations as well as to our present dependence on petroleum-based agrochemical inputs. Also, patterns of agricultural production and consumption that involve long-distance movement of commodities will become less economic as transport costs rise. This will make local production economically more competitive with distant agricultural operations that were previously considered to have a comparative advantage. Moreover, the increasing use of grains to manufacture biofuels in response to the rising prices for energy contributes to increased prices of food grains, which adversely affects particularly the food-insecure.

- Environmental concerns are affecting the acceptability of various agricultural practices in many places. Negative externalities such as adverse effects on water, soil and air quality and biodiversity losses are becoming less tolerated than in the past, given larger and denser human populations and more urban political influence.

- Pest and disease problems are likely to increase, partly in response to climate changes, but also with pest resistance to agrochemical controls as a factor. Despite a 14-fold increase in the amount of pesticides used in the US after World War II, the percentage of crops lost to pests increased in this period from $6 \%$ to $13 \%$ [3]. The theory of 'trophobiosis' may help account for this phenomenon of chemical-induced vulnerability of crops to pest and disease losses [4].

- Climate changes will make all of these other trends more challenging for agricultural producers. Altered temperature and rainfall patterns will not be felt equally because there will be winners and losers from change; but especially the poorer countries, and the more marginalized farmers within them, appear likely to bear the greatest brunt of new weather regimes and of the greater uncertainty and variability that these bring. 'Extreme events' are likely to become both more frequent and more extreme: droughts, storms, flooding, heat waves, cold periods, disadvantaging both producers and consumers at the same time.

- To make matters worse, government capabilities to deal with these many problems appear less coherent, less stable, and less statesmanlike, with less commitment and less ability to achieve effective functioning of their economies, societies and administrations. Our legislative and governing bodies are increasingly beset by narrow partisanship and jockeying for short-term personal or factional advantages. Also, we are seeing in many parts of the world an attenuation of cultural and political inhibitions against large-scale use of violence - that genie which governments previously kept bottled up with at least some success.

- Governments' fiscal capacities are almost everywhere stretched to the breaking point. Accumulating debts and voter disaffection are reducing public-sector willingness and ability to invest in (or subsidize) inputs and improvements in 
agriculture, even though the central importance of food has not diminished. Farm subsidies and export restrictions in many countries, maintained as a result of governments' political weakness rather than strength, continue to exert upward pressures on food grain prices that affect the food-insecure.

- Furthermore, the forces of globalization, while they may open up many opportunities, seem also to contribute to socio-economic instability and inequity that make national governance ever more difficult. Simply the greater scale and complexity of modern societies and economies appears to be making our institutions and practices of governance less effective.

- Slowing gains in agricultural productivity cast an ominous shadow over this whole scene. The rates of growth in cereal production during the 1970s and 1980s were truly remarkable, although we should notice that the rate of yield increase was even higher in the 1960s before Green Revolution technologies began taking effect. World grain production per capita, according to FAO and USDA statistics, peaked in 1984, with the rate of grain production increases falling ever since. The world's total grain production has been stagnant or declining since the mid-1990s [5-7].

- The global food crisis in 2007 to 2008 with its huge price jumps was prompted by multiple factors; but an underlying cause was the tightening of world food supplies relative to demand. It is true that with available resources and improved technology, more food could have been produced in recent years if there had been higher market prices for food. However, if food had been more expensive, this would have increased the extent of hunger and poverty in the world, both of which are still unacceptably pervasive.

All these considerations make it imperative to find ways to raise our agricultural productivity, to make our available resources, land, labor, water and capital more productive. We need to be enhancing food supply particularly on the basis of productivity gains rather than trying to evoke more food production through the incentive of higher prices, as this will increase food insecurity for millions of households.

There are ongoing efforts to improve food security through genetic improvements that focus on yield, resistance to various biotic and abiotic stresses, and improved nutritional value through biofortification. While some of these gains may be some years away, they are worth pursuing. But in the present and near future, we need to be achieving greater productivity of the key factors of production: land, labor, and especially water, as well as capital.
The more resources which are require for meeting people's food needs, the fewer resources are available for meeting other needs, for investment in human resources, for housing and infrastructure, for expanding research and development in other fields. Resources expended in food production cannot be used to improve output and well-being in other sectors. This makes the quest to find ways to produce more food with fewer resources important for the whole world as we head into an uncertain, fairly ominous future.

\section{Capitalizing on existing biological opportunities}

Making improvements in our global ability to meet people's needs for sustenance will not solve all of the many problems that face our governments and societies around the world. But if we cannot produce and provide sufficient food to everyone - if we tolerate large pockets of hunger and misery, and have large domains of desperation with loss of hope for the future - most of the other problems that loom on the global agenda will remain beyond solution.

The limited and, in many respects, shrinking resources that are available for agricultural production dictate that we intensify our production practices rather than continue with the land-extensive strategies that expanded in the 20th century, relying heavily on mechanization and economies of scale. In the 21st century, these strategies for food production, being energy-intensive and chemical-dependent, will become less attractive and indeed less economically viable as factor proportions and relative prices change.

The word 'intensification' when applied to agricultural production has usually referred to an intensification of input use [8]. The logic of such intensification - and the cost-benefit analysis that guides it - has been to compare how much more of what inputs will yield how much more in resulting outputs? If the value of the resulting outputs from production is sufficiently greater than the cost of the inputs needed to produce them, this represents a net gain. This strategy has been bolstered by plant-breeding efforts which have developed genotypes that are more responsive to additional inputs of water, fertilizer, and agrochemicals. There has been an underlying assumption that we always need to increase inputs to raise production, with the expectation that a greater increase in outputs will result to justify the expenditure.

An alternative kind of intensification is the intensification of management involving both more knowledge and skill - to achieve more output from whatever inputs are used. Both approaches, of course, confront the limitations of diminishing returns. Management here refers to making modifications in, and manipulations of, the growing environment $(\mathrm{E})$, aiming to produce better phenotypes $(\mathrm{P})$ from the genotypes $(\mathrm{G})$ in use. This is 
represented by the symbolic equation well-known to plant breeders:

$$
\mathrm{P}=f(\mathrm{G} \times \mathrm{E})
$$

Current agricultural development efforts focus particularly on improving $G$ to achieve maximum increases from the resources invested. A management-oriented strategy, conversely, starts with the best available G, focusing on how to improve those factors that constitute the $\mathrm{E}$ for their crops' growing environments both above and below ground. The logic of cost-benefit analysis is turned on its head when we try to calculate a ratio between reduced inputs and greater output. This may be why agroecological alternatives are widely viewed with skepticism.

\section{Raising food production, especially for the food-insecure}

An agroecological innovation that has demonstrated remarkable gains in food output is the System of Rice Intensification (SRI) developed in Madagascar [9-11]. This methodology for raising the productivity of all the resources devoted to rice production (land, labor, seeds, water and capital) departs from the intensification strategy that relies on new varieties with genetic improvement and then on greater external inputs.

Instead, the productivity gains from SRI management derive from changes made in the way that the rice plants, soil, water and nutrients are managed; their timing, spacing, and so on. The phenotypical changes resulting from modifications in management are easily seen (Figures 1 and 2) and have been documented and explained by many researchers, for example [12-16]. Over 300 published articles on SRI are listed now on the SRI-Rice website at http://sri.ciifad.cornell.edu/research/ index.html\#journals. Results vary considerably because the changes achieved derive more from biological processes, which are vulnerable as well as potent, than from genetic blueprints or material inputs. The preponderance of evidence is certainly positive.

The yield effects of intensifying crop management with SRI methods have been a matter of some controversy among rice scientists, for example [17-20]. But governments in China, India, Indonesia, Cambodia and Vietnam, where two-thirds of the world's rice is produced, have become satisfied from their own evaluations that factor productivity is greatly enhanced by SRI changes in rice crop management. Two of the world's most eminent rice scientists, Dr. MS Swaminathan and Prof. Yuan Long-ping, have satisfied themselves from their own evaluations that SRI methods lead to more productive rice plants and have recommended SRI use in their respective countries, India and China [21].

In 2007 the Ministry of Agriculture and Rural Development in Vietnam, after three years of evaluations, concluded and declared that SRI represented a 'technical advance'. At that time, fewer than 10,000 Vietnamese farmers were using SRI methods. Four years later, in 2011, the Ministry announced that over 1 million Vietnamese farmers were using most or all of the recommended SRI practices - with higher yields, less water, lower production costs, and improvements in environmental quality [22]. See news report at http://qdnd.vn/qdndsite/en-US/75/72/ 182/156/189/164012/Default.aspx.

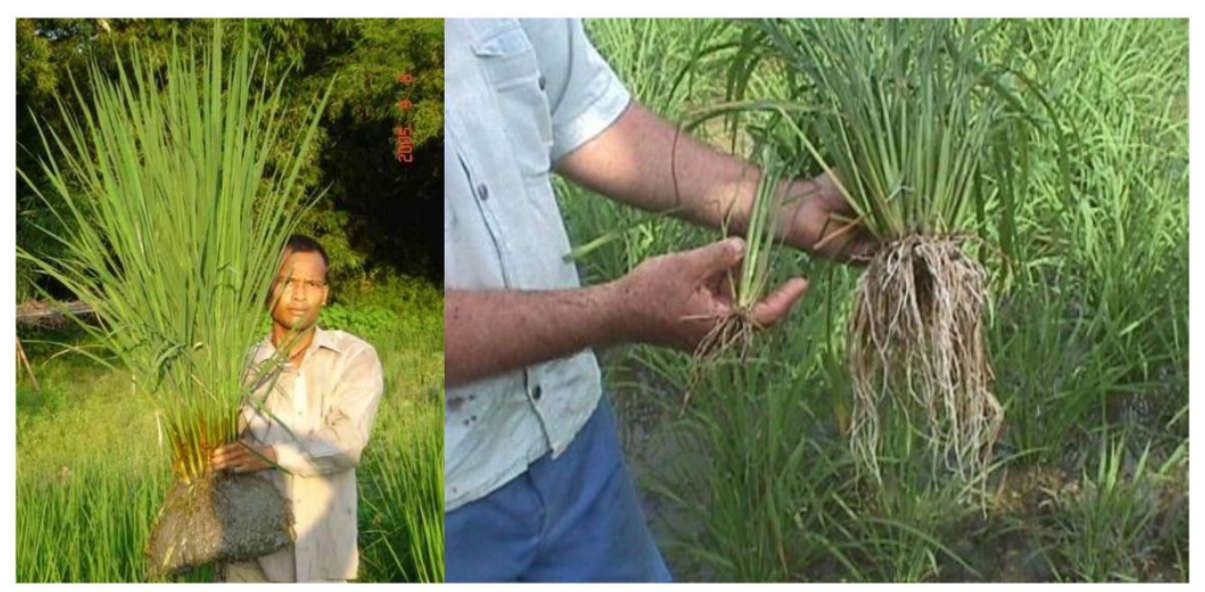

Figure 1 Phenotypical effects of SRI (System of Rice intensification) management: (a) Nepali farmer on left holds a rice plant grown with SRI methods from a single seed; (b) on right, a Cuban farmer holds two rice plants of the same variety (VN2084) and same age (52 days after sowing). Both Cuban plants were started in the same nursery, but the plant on right was removed at 9 days and was transplanted into a field where SRI growing conditions were maintained. A video showing, week by week, the contrasting and divergent growth of SRI and conventional rice plants on this same Cuban farm in the following year is posted at: http://www.youtube.com/watch?

v=1zOMiglbao4\&feature=relmfu. Pictures courtesy of Rajendra Uprety, District Agricultural Development Office, Biratnagar, Nepal; and Dr. Rena Perez, then food security advisor, Ministry of Sugar, Havana, Cuba. 


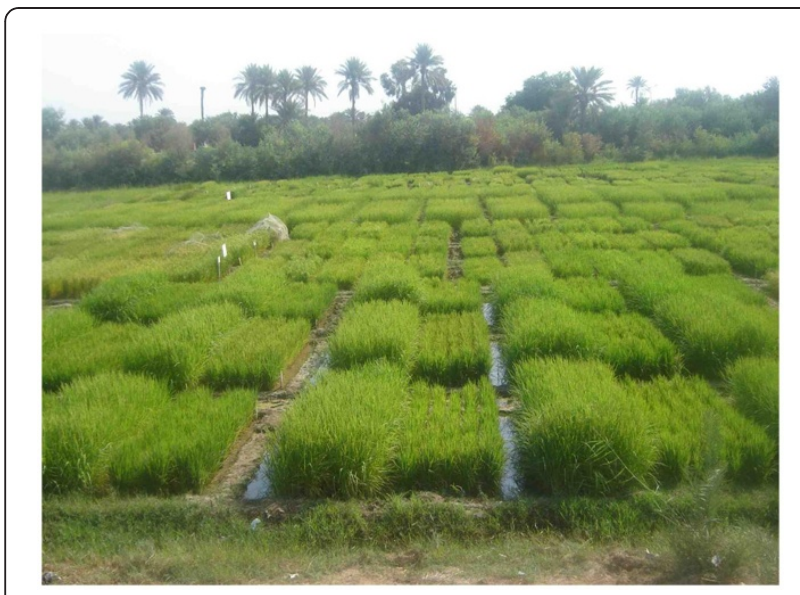

Figure 2 Comparisons of growth response of different varieties to SRI (System of Rice Intensification) management: trial plots at Al-Mishkhab Rice Research Station, Najaf, Iraq, evaluating differences in varietal response to SRI methods. On the left in each pair of trials are SRI plants, being compared with rice plants of same variety grown with current best management practices on right. Picture courtesy of Dr. Khidhir Hameed, MRRS.

The management changes introduced with SRI include: use of younger seedlings if the rice crop is established by transplanting (note: direct-seeding is also beginning to be used with the other SRI practices); greatly reduced plant populations by planting single seedlings in widely-spaced hills; no continuous flooding of paddy fields; controlling weeds with a mechanical weeder that aerates the soil; plus enhancement of the soil's organic matter as much as possible.

When these methods are used together as recommended, yield increases have ranged from $20 \%$ to $100 \%$ or sometimes even more, with large reductions in seed requirements (by 80 to $90 \%$ ), in irrigation water (by a quarter to a half), in chemical fertilizer (by $50 \%$ or even $100 \%$ ), and in applications of agrochemicals (varying, according to how much pest and disease resistance is engendered by SRI methods). Often labor requirements are also reduced once the methods have been learned and mastered. Unfortunately, SRI was initially regarded and dismissed by some as too labor-intensive for farmer acceptance; however, many farmers in China and India consider reduction in labor requirements to be one of SRI's main attractions, particularly for women. Table 1 gives a summary overview of SRI results across 13 countries, as assessed by a variety of institutions - international agricultural research centers, universities, government agencies, NGOs, private firms (Nippon Koei and Syngenta/Bangladesh), and a donor agency (GTZ).

It is understandable that SRI results have been received with some incredulity. However, the bases for these increases in productivity are becoming better understood. The most evident factor is the greater root growth induced by SRI methods (Figure 1b). Less visible but now being documented are the methods' impacts on soil biota that provide benefits to rice crops [42-45]. Similar benefits are now being seen when SRI methods have been adapted to other crops such as wheat and sugarcane $[46,47]$, finger millet, mustard, tef, and some legumes and vegetables. This adds credibility to the remarkable results that have been reported for rice.

For some years, skeptics rejected SRI because they considered some of its reported results to be impossible. The top yields reported from Madagascar were characterized as being above the biological maximum achievable with rice [18]. However, in the 2011 kharif season in the Indian state of Bihar, five first-time SRI farmers in one village (using hybrid varieties) matched or exceeded the previous world-record yield for paddy of 19 tons/ha. According to Bihar Department of Agriculture data, one achieved a yield of 22.4 tons/ha, almost ten times the average paddy yield for the state. The dry weight was an unprecedented 20.16 tons/ha [48]. These measurements, made with standard methods and with hundreds of observers looking on, have been officially accepted.

The controversy over SRI maximum yields has unfortunately deflected attention from the large differences in average yields, which should have been the central focus of discussion. SRI methods have often enabled poor farmers to double, triple or even quadruple their yields, not just individually but on a village level, without having to purchase new varieties or agrochemical inputs [49-52]. Such resource-limited farmers started at very low levels of production, it is true. But for them, to go from 1 ton per hectare to 4 tons, or from 2 tons to 8 tons, without added costs of production, makes a huge difference in their food security and well-being. For the 2011 kharif season, the Bihar Department of Agriculture in India has calculated an average SRI yield of 8.08 tons/ ha on 335,000 hectares across all 38 districts of the state. This was more than three times the state-wide average of 2.5 tons/ha.

It has been argued that the 'best management practices' (BMP) recommended by scientists can give better results than reported from SRI practices [53]. However, the evidence and analysis presented to support this claim are seriously flawed [54]. More importantly, the paddy yields reported above from Bihar state show the argument to be simply wrong; SRI methods can surpass what best conventional practices can achieve by yielding more productive phenotypes. The five Bihar farmers who got SRI yields matching or exceeding the previous world record got less than half as much yield from their hybrid varieties when these were grown on the same farms, with the same soil and same climate, using conventional crop management methods. 
Table 1 Review of SRI management impacts on yield, water saving, costs of production, and farmer income per ha in 13 countries

\begin{tabular}{|c|c|c|c|c|c|c|c|c|}
\hline Country & $\begin{array}{l}\text { Farmers }(\mathrm{N}) \text { or } \\
\text { Trials/Area }\end{array}$ & $\begin{array}{l}\text { Conven- } \\
\text { tional } \\
\text { yield (t/ha) }\end{array}$ & $\begin{array}{l}\text { SRI } \\
\text { yield } \\
\text { (t/ha) }\end{array}$ & $\begin{array}{c}\text { Yield } \\
\text { increase } \\
(\%)\end{array}$ & $\begin{array}{l}\text { Water } \\
\text { saving } \\
(\%)\end{array}$ & $\begin{array}{l}\text { Impact on } \\
\text { cost per } \\
\text { ha (\%) }\end{array}$ & $\begin{array}{c}\text { Impact on } \\
\text { income per ha } \\
(\%)\end{array}$ & $\begin{array}{l}\text { Coverage of evaluation } \\
\text { and agency doing study } \\
\text { [source of data] }\end{array}$ \\
\hline AFGHANISTAN & $42^{d}$ & 5.6 & 9.3 & $55 \%$ & NM & NM & NM & $\begin{array}{c}\text { Aga Khan Foundation program } \\
\text { in Baghlan district [23] }\end{array}$ \\
\hline BANGLADESH & $1,073^{d}$ & 5.44 & 6.86 & $26 \%$ & NM & $-7 \%$ & $+59 \%$ & $\begin{array}{c}\text { 2-year study by NGOs and } \\
\text { Syngenta under IRRI program } \\
\text { auspices }[24]\end{array}$ \\
\hline CAMBODIA & $500^{c}$ & 1.63 & 2.29 & $41 \%$ & Rainfed & $-56 \%$ & $+74 \%$ & $\begin{array}{l}\text { 5-province study done for } \\
\text { GTZ [25] }\end{array}$ \\
\hline $\begin{array}{l}\text { Experienced } \\
\text { farmers }\end{array}$ & $120^{d}$ & 1.34 & 2.75 & $105 \%$ & Rainfed & $-47 \%$ & $+98 \%$ & $\begin{array}{c}\text { Study of all 3-year SRI users } \\
\text { by CEDAC [26] }\end{array}$ \\
\hline CHINA & $82^{c}$ & 6.6 & 9.37 & $42 \%$ & $44 \%$ & $-7.4 \%{ }^{f}$ & $+64 \%$ & $\begin{array}{l}\text { Village study by China } \\
\text { Agricultural University in } \\
\text { Sichuan province [27] }\end{array}$ \\
\hline $\begin{array}{l}\text { Sichuan } \\
\text { province }\end{array}$ & $\begin{array}{l}\text { Total area } 2004 \text { to } 2010 \text { : } \\
301,967 \text { ha }\end{array}$ & 7.7 & 9.5 & $23 \%$ & $25.6 \%$ & NR & $\begin{array}{l}\text { Additional income: } \\
\text { US\$320 million }\end{array}$ & $\begin{array}{l}\text { Provincial Department of } \\
\text { Agriculture data, } 2004 \text { to } \\
2010 \text { [28] }\end{array}$ \\
\hline INDIA & $108^{d}$ & $4.12^{9}$ & $5.47^{\mathrm{g}}$ & $32 \%{ }^{9}$ & Rainfed & $-35 \%$ & $+67 \%$ & $\begin{array}{l}\text { IWMI-India programme study } \\
\text { in W. Bengal [29] }\end{array}$ \\
\hline $\begin{array}{l}\text { Andhra } \\
\text { Pradesh state }\end{array}$ & $1,525^{d}$ & 6.31 & 8.73 & $34 \%$ & $40 \%$ & NM & NM & $\begin{array}{l}\text { Evaluations by AP state } \\
\text { university ANGRAU [30] }\end{array}$ \\
\hline INDONESIA & $12,133^{d}$ & 4.27 & 7.61 & $78 \%$ & $40 \%$ & $-20 \%$ & $>100 \%$ & $\begin{array}{l}\text { On-farm trials managed by } \\
\text { Nippon Koei TA team, } 2002 \\
\text { to } 2006[31]\end{array}$ \\
\hline KENYA & On-station trials & 6.2 & 7.6 & $26 \%$ & $28.2 \%$ & NM & NM & $\begin{array}{l}\text { Mwea irrigation scheme } \\
\text { trials, } 3 \text { replications [32] }\end{array}$ \\
\hline $\begin{array}{l}\text { Additional } \\
\text { trials }\end{array}$ & $"$ & 8.66 & 14.85 & $70 \%$ & $24 \%$ & NM & NM & $\begin{array}{l}\text { Mwea irrigation scheme } \\
\text { trials, } 4 \text { replications [33] }\end{array}$ \\
\hline MALI & $53^{d}$ & 5.5 & 9.1 & $60 \%$ & $10 \%$ & $+15 \%$ & $+108 \%$ & $\begin{array}{l}\text { Timbuktu region under } \\
\text { Africare program [34] }\end{array}$ \\
\hline MYANMAR & $612^{d}$ & 2.1 & 4.4 & $110 \%$ & Rainfed & $+0.2 \%$ & 8.7 times more & $\begin{array}{l}\text { FFS results in Kachin and } \\
\text { Shan States, } 3 \text { years [35] }\end{array}$ \\
\hline NEPAL & $412^{d}$ & 3.3 & 6.1 & $82 \%$ & $43 \%$ & $-2.2 \%^{\mathrm{e}}$ & $+163 \%$ & $\begin{array}{c}\text { District agricultural extension } \\
\text { program, Morang [36] }\end{array}$ \\
\hline $\begin{array}{l}\text { Far Western } \\
\text { region }\end{array}$ & $890^{d}$ & 4.01 & 7.58 & $88 \%$ & $>60 \%$ & $+32 \%$ & $+164 \%$ & $\begin{array}{l}\text { EU-FAO Food Facility } \\
\text { Programme }[37,38]\end{array}$ \\
\hline PANAMA & $46^{d}$ & 3.44 & 4.75 & $38 \%$ & $71-86 \%$ & NM & NM & $\begin{array}{c}10 \text { communities, evaluation } \\
\text { by NGO [39] }\end{array}$ \\
\hline SRI LANKA & $120^{c}$ & 3.84 & 5.52 & $44 \%$ & $24 \%$ & $-12 \%$ & $+104 \%$ & IWMI study in 2 districts [40] \\
\hline VIETNAM & $1,274^{d}$ & 5.58 & 6.79 & $22 \%$ & $33 \%$ & $-30 \%$ & $+36 \%$ & $\begin{array}{l}\text { MARD FFS results from } 13 \\
\text { districts [41] }\end{array}$ \\
\hline $\begin{array}{l}\text { Total } \mathrm{N} \text { and } \\
\text { Averages }\end{array}$ & $18,870^{a}$ & 4.77 & 7.12 & $50 \%$ & $37.5 \%$ & $-16 \%$ & $94 \%{ }^{a, b}$ & \\
\hline
\end{tabular}

NM: Not measured, NR: Not reported, FFS: Farmer Field Schools.

${ }^{a}$ Not including Sichuan/China data; ${ }^{b}$ Not including Myanmar data.

${ }^{c}$ Based on random samples; ${ }^{d}$ Results from all farmers using SRI in area; no sampling involved.

e Labor-saving hand weeders were not yet available in district to reduce labor inputs and costs.

${ }^{f}$ Extension personnel were promoting the purchase of modern seeds and fertilizer simultaneously with SRI methods.

${ }^{9} 50 \%$ increase in the village with normal rainfall, $12 \%$ in the drought-stricken village.

The contention that BMPs are superior to SRI disregards the fact that many millions of small and marginal farmers do not have access to, or cannot afford, the new seeds and other inputs required for what are considered as BMP. For hunger and poverty to be reduced, we need methods that substantially improve farmers' productivity with the resources and means that they have at hand. A variety-based, input-dependent strategy of agricultural 
development has inherent limitations for reducing world hunger and food insecurity in a significant way.

\section{Re-biologizing agriculture}

Experience with SRI methods has directed our attention to the symbiotic relationships between plants and soil microbes, which parallel the growing realization that humans and other members of the animal kingdom are themselves thoroughly interdependent with, and for that matter, dependent on microorganisms, referred to collectively for humans as the human microbiome [55]. The microbiomes of plants are no less important. Appreciating this fact re-focuses our thinking from engineering and chemical solutions to capitalizing more upon biological and ecological processes and potentials.

It has long been known that the root zones (rhizospheres) of plants are domains of intense and mutually beneficial interaction between plant roots and soil organisms [56,57]. Research has shown that certain soil organisms in fact inhabit the leaves, sheaths and stalks of rice plants, that is, their phyllosphere; and controlled trials have demonstrated that this 'infection' of aboveground plant tissues by soil bacteria is associated with the plants having larger canopies and root systems, higher levels of chlorophyll and more photosynthesis in their leaves, greater water-use efficiency, and higher yield $[15,58]$.

Moreover, the presence of soil rhizobia in the tissues of leaves and sheaths of rice plants has been seen to upregulate certain genes that produce proteins supportive of photosynthesis and other functions in the canopy; and these same microorganisms, in the roots of rice plants, enhance the expression of genes in tissues there that produce proteins conferring greater protection against pathogens [59]. Plant growth and performance are thus assisted by the presence and influence of soil microbes.

Signaling between roots and shoots via phytohormones has been shown to contribute to higher yield with reduced fertilizer inputs and to healthier plants that resist pathogens [60]. Even more surprising may be the results of replicated trials in which rice plants grown from seeds inoculated with a certain fungus (Fusarium culmorum) have been found to have five times more root growth in their early days after germination, and their root hairs emerge two days sooner. The fungus, when residing in seeds, enhances the plants' ensuing growth and robustness [61].

The contributions that symbiotic endophytes, microbes living mutualistically within plant tissues and cells, can make to crop performance and health are becoming more evident [62]. Learning how to utilize and benefit from positive microbial influences could possibly enhance crop productivity in parallel with the improvements that are expected to be made in human health as a result of contemporary research on the human microbiome. Research on the microbiomes of crop plants should be similarly productive.

\section{Focusing research on ecological rather than only on species productivity}

These findings suggest that we consider making some shifts in the predominant focus for agricultural research. Present strategies are based on ever-increasing use of inputs in conjunction with making improvements in genotypes, with a species focus. There is reason to explore more how improving crops' environments above and below ground through changes in plant, soil, water and nutrient management can elicit more beneficial expression of crops' genetic potentials, recognizing that these are affected by ecological factors.

The focus should be not just on producing more grain, but also on growing plants that can better resist the biotic and abiotic stresses that are likely to become more common as a result of impending climate changes. The impetus for this reorientation is coming not so much from research stations as from farmers' fields, where producers are contending directly with the factors that contribute to food security or insecurity (Figures 3 and 4).

Previously, agricultural researchers have focused separately on individual species of plants or animals in isolation from other species. Finding ways to capitalize upon symbiotic relationships among various species - considering sets of species together in ecological perspective, such as with the 'push-pull' crop management system developed in East Africa to deal with striga infestation can create multiple benefits at low cost [63].

Soil scientists have been evaluating plants' performance often under axenic soil conditions, where all life in the soil has been eliminated by fumigation or sterilization. If the effects of soil organisms are studied, possibly just one or two species would be added back to look at their effect under what are called gnotobiotic conditions in otherwise axenic soil. This latter word is curious because 'axenic' is constructed from Greek semantic roots which mean 'without strangers' $(a+x e n o s)$. This formulation implies that soil organisms are to be considered as strangers or foreigners within their own natural habitat [64].

Future agricultural research, in light of recent findings, will do well to examine the performance of crops and livestock within their ecological contexts. Species improvement should be attempted in the context of interactions with other species rather than in isolation. This is one way in which we can 're-biologize' agriculture, having been guided for the past half century more by the disciplines of chemistry and engineering in league with 


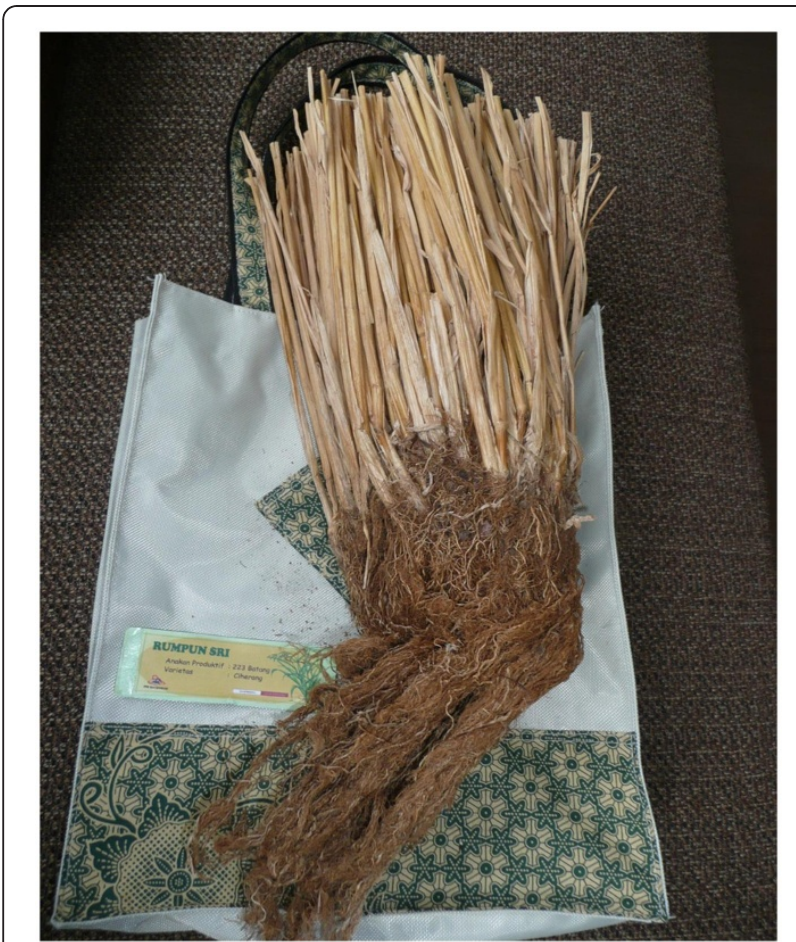

Figure 3 Effects on root and tiller growth with modified rice management: stump of a rice plant with 223 tillers, grown with SRI methods from a single seed, presented to the author in October 2009 by farmers in a farmer field school at Panda'an, East Java, Indonesia, operated by the Sampoerna Foundation as a corporate social responsibility project. This was the farmers best plant from the previous season, but it showed them what a single seed could produce with optimum growing conditions. Picture by author.

the science of genetics. The disciplines of microbiology, soil ecology, and epigenetics will, foreseeably, become more prominent within the agricultural sciences, focusing in particular on understanding better how genetic potentials are expressed (epigenetics), appreciating that it is phenotypes and not genotypes that we consume as food.

\section{Some implications for plant breeding}

SRI practitioners have found that the greatest yields obtained with their methods have come from what are called high-yielding varieties (HYVs) or hybrids. So, agroecological approaches do not negate the basis for genetic research. The world-record yield reported above was with a hybrid variety with application of some inorganic fertilizer, although there was primary reliance on organic fertilization, that is, on integrated nutrient management [48]. It is also true, however, that many local or indigenous varieties also respond well to SRI management, with some giving yields over 10 tons/ha. (The world average is about 4 tons/ha.) Since the market price for local varieties is often higher because of consumer

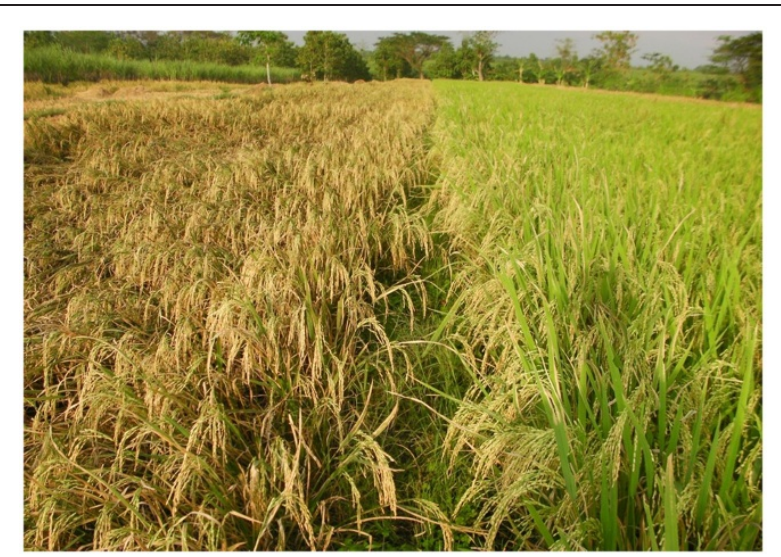

Figure 4 Resistance to biotic and abiotic stresses based on alternative crop management: two adjacent rice paddy fields in Crawuk village, Ngawi district, East Java, Indonesia, after they were both hit by a brown planthopper (BPH) attack and then by a tropical storm in June 2011. Paddy field on left, planted with an improved rice variety (Ciherang) and using inorganic fertilizer and agrochemical protection, gave almost no yield because of $\mathrm{BPH}$ burn and lodging. From the field on the right, 1,000 $\mathrm{m}^{2}$ in area, planted with an aromatic unimproved variety (Sinantur) and having organic SRI management, $800 \mathrm{~kg}$ was harvested, a yield of 8 tons/ha. Picture given to the author by Ms. Miyatty Jannah, the farmer who

managed the field on right.

taste and other preferences, growing 'unimproved' cultivars with SRI practices can be more profitable than using HYVs.

The kind of plant breeding that Norman Borlaug and his colleagues undertook has been very successful and deserves our appreciation. But it may not be as suitable a strategy for the emerging conditions that will be faced in the decades ahead. Both breeding and management are essential for success, combining the effects of $\mathrm{G}$ and $\mathrm{E}$; that is clear. But since the 1990s there have been diminishing returns from breeding strategies, whereas over the past decade we have been seeing from SRI experience that very great impacts on yield can be achieved by making changes in crop management, as apparently this has beneficial impacts on crops' relationships with their microbial symbionts [43,45].

One can find very little in the Green Revolution literature that examines the contributions of roots and soil biota to plants' health and growth. These are the factors that SRI experience and its extrapolation to other crops are pointing to as very potent. For decades, plant breeders have sought through genetic improvements to raise the Harvest Index (HI), that is, the proportion of plant biomass that is found in the edible portion. But the focus has all been on above-ground plant organs. The biomass in plant roots has not even been considered when calculating $\mathrm{HI}$.

The abundant growth of roots has been largely ignored or even deprecated by plant breeders, much as profuse 
tillering has been disapproved. The prolific growth of roots and shoots was thought to be wasteful and in competition with - rather than supportive of - grain production. (I have been told, twice, by a senior agronomist in the US that 'roots are a waste', because they lower the Harvest Index). However, crops in this current century will need to be more naturally resistant to pest and disease assaults and to be buffered from drought, from rain and wind damage, and from temperature stresses. Root development and more abundant, more diverse soil biota are likely to become more appreciated for their promotion of crop resilience and for their enhancement of productivity in the face of climate-change pressures.

\section{Future research opportunities and modes of operation}

There is widespread agreement on the need for 'another Green Revolution', but the operational shape and direction of this effort remains to be determined. Agricultural scientists have begun to investigate and evaluate SRI methods only in the last few years, and these methods are rapidly spreading to other crops with similar effects. SRI ideas and methods were developed inductively by a Jesuit priest [65] based on observations and field experimentation, so there are surely many opportunities for scientists to make improvements and to determine limitations in this methodology.

The symbiotic relationships between crops and beneficial microorganisms appear to be a particularly fruitful area for research $[43,61]$. Studying rhizosphere biology can illuminate changes in underground dynamics that occur when plants are grown using SRI methods. For example, spatial and temporal variations in redox gradients can lead to qualitative and quantitative changes in microbial populations and activity $[42,66]$. Recent analysis has underscored the importance of optimizing redox potential which has its basis in soil biology as much as soil chemistry and soil physics [67].

Research at the Indian Agricultural Research Institute has shown that SRI methods of cultivation not only increased water productivity (with a $27 \%$ saving of irrigation water in these trials), but they also enhanced soil microbial activity, micronutrient uptake, and the $\mathrm{N}$ content in both soil and grain, compared to conventional transplanting methods $[45,68]$. Biofertilizers and microbial inoculants when used with SRI management may further contribute to the prolific growth of roots and facilitate nutrient mobilization and uptake in rice, with improvements in grain quality. Much research remains to be done.

Along with a refocusing of research in microbiological directions, it should be noted that SRI experience encourages agricultural scientists to work more closely with practitioners, both farmers and NGO personnel, who presently have more knowledge of this innovation than anyone else. Advances in the future are likely to come from observations, experience and thinking from many sources, not just from the formal agricultural disciplines.

\section{Conclusions}

There is no reason to think that SRI and other agroecological concepts and practices will replace all other kinds of agriculture; agricultural change does not proceed so discontinuously. Norman Borlaug reasonably insisted that agricultural development be science-based. This means that innovations should be examined and evaluated objectively and systematically, although this does not mean that all innovations must originate from the formal scientific community, or that knowledge and data coming from sources other than credentialed scientists should be excluded from consideration.

\section{Competing interests}

The author declares that he has no competing interests, having no financial stake in this subject, although he has been personally and professionally involved with trying to make improvements in food security internationally for more than 40 years. He has been directly involved in encouraging the evaluation and, where warranted, dissemination of SRI along with other agroecological innovations for the past 15 years.

\section{Authors' information}

Norman Uphoff has been on the faculty of Cornell University since 1970 as a professor of government and (since 1990) of international agriculture. From 1990 to 2005, he served as director of the Cornell International Institute for Food, Agriculture and Development (CIIFAD), and he is currently director of the Cornell Institute for Public Affairs (CIPA), while also senior advisor to the SRI International Network and Resources Center (SRI-Rice) based in CIIFAD.

\section{Acknowledgements}

This paper updates a presentation made at a forum organized by the Norman Borlaug Foundation at the 2010 BioVision Alexandria International Conference, held at the Alexandria Library in Egypt in April 2010. Inputs from Dr. Radha Prasanna, senior scientist in the Indian Agricultural Research Institute, New Delhi, are gratefully acknowledged.

Received: 30 July 2012 Accepted: 9 October 2012

Published: 1 December 2012

\section{References}

1. Hayami Y, Ruttan WW: Agricultural Development: An International Perspective Baltimore: Johns Hopkins University Press; 1985.

2. UN Environmental Program: The Environmental Food Crisis: environment's Role in Averting Future Food Crises. Nairobi; 2005. http://www.grida.no/ publications/rr/food-crisis/.

3. Pimentel D: Techniques for Reducing Pesticides: Environmental and Economic Benefits. Chichester, UK: John Wiley; 1997.

4. Chaboussou F: Healthy Crops: A New Agricultural Revolution. Charnley, UK: Jon Anderson Press; 2004.

5. Pingali PL, Hossain M, Gerpacio RV: Asian Rice Bowls: The Returning Crisis? Wallingford, UK: CAB International; 1997.

6. Dyson T: World food trends and prospects to 2025. Proc Natl Acad Sci (US) 1999, 9:5929-5936.

7. Uphoff N: Agricultural futures: What lies beyond 'modern agriculture'? Trop Agric Assoc Newsletter 2007, 27:13-19. http://www.bioscienceresource. org/cms/documents/TAA\%20\%20Bunting\%20Lecture.pdf.

8. Reichardt W, Dobermann A, George T: Intensification of rice production systems: opportunities and limits. In Rice in the Global Food System. Edited by Dowling NG, Greenfield SM, Fischer KS. Los Baños: International Rice Research Institute; 1998:127-144. 
9. Uphoff N: Opportunities to achieve resource-conserving increases in agricultural productivity: learning from the System of Rice Intensification (SRI). In New Life Sciences: Future Prospects - Proceedings of BioVision Alexandria 2010. Edited by Serageldin I, Masood E, El-Faham M, El-Wakil M. Alexandria: Biblioteca Alexandrina; 2011. http://www. bibalex.org/BVA2012/attachments/staticpages/file/Publications/ BVA2010_Web.pdf.

10. Stoop WA, Uphoff N, Kassam A: A review of agricultural research issues raised by the system of rice intensification (SRI) from Madagascar: opportunities for improving farming systems for resource-poor farmers. Agric Syst 2002, 71:249-274.

11. Uphoff N, Kassam A: Case study: System of Rice Intensification. In Agricultural Technologies for Developing Countries: Final Report, Annex 3. Brussels: European Parliament; 2009.

12. Hameed KA, Mosa AKJ, Jaber FA: Irrigation water reduction using System of Rice Intensification (SRI) compared with conventional methods in Iraq Paddy Water Envir 2011, 9:121-127.

13. Lin XQ, Zhu DF, Chen HZ, Cheng SH, Uphoff N: Effect of plant density and nitrogen fertilizer rates on grain yield and nitrogen uptake of hybrid rice (Oryza sativa L.). J Agric Biotech \& Sust Dev 2009, 1:44-53.

14. Mishra A, Salokhe VM: Seedling characteristics and early growth of transplanted rice under different water regimes. Exper Agric 2008, 44:1-19.

15. Thakur A, Uphoff N, Antony E: An assessment of physiological effects of system of rice intensification (SRI) practices compared to recommended rice cultivation practices in India. Exper Agric 2010, 46:77-98.

16. Zhao LM, Wu LH, Li YS, Lu XH, Zhu DF, Uphoff N: Influence of the System of Rice Intensification on rice yield and nitrogen and water use efficiency with different $\mathrm{N}$ application rates. Exper Agric 2009, 45:275-286.

17. Dobermann A: A critical assessment of the system of rice intensification (SRI). Agric Syst 2004, 79:261-281.

18. Sheehy JL, Peng SB, Dobermann A, Mitchell PL, Ferrer A, Yang JC, Zou YB, Zhong $\mathrm{XH}$, Huang $\mathrm{J}$ : Fantastic yields in the system of rice intensification: fact or fallacy? Field Crops Res 2004, 88:1-8.

19. Sinclair TR, Cassman KG: Agronomic UFOs. Field Crops Res 2004, 88:9-10

20. Stoop WA, Kassam AH: The SRI controversy: a response. Field Crops Res 2005, 91:357-360.

21. Uphoff N: Comment to 'The System of Rice Intensification: time for an empirical turn' [NJAS: Wageningen Journal of Life Sciences 57 (2011) 217-224]. NJAS: Wageningen J Life Sci 2012, 59:53-60.

22. Castillo GE, Minh NL, Pfeifer K: Oxfam America: learning from the System of Rice Intensification in Northern Vietnam. In Scaling Up in Agriculture, Rural Development and Nutrition. Edited by. Washington DC: International Food Policy Research Institute; 2012. Brief No. 15.

23. Thomas $V$, Ramzi MA: SRI contributions to rice production dealing with water management constraints in northeastern Afghanistan. Paddy Water Envir 2011, 9:101-109.

24. Husain AM, Chowhan G, Barua P, Razib Uddin AFM, Ziaur Rahman ABM: Final Evaluation Report on Verification and Refinement of the System of Rice Intensification (SRI) Project in Selected Areas of Bangladesh (SP 36 02). Dhaka, Bangladesh: Report to IRRI/Bangladesh Programme from BRAC, POSD, SAFE and Syngenta/Bangladesh Ltd; 2004.

25. Anthofer J: The potential of the System of Rice Intensification (SRI) for poverty reduction in Cambodia. Berlin: Phnom Penh: Summary of report prepared for GTZ; 2004. http://www.tropentag.de/2004/abstracts/full/399.pdf.

26. Tech C: Ecological System of Rice Intensification (SRI) Impact Assessment (2001-2003). Phnom Penh: Report of the Cambodian Center for Study and Development in Agriculture (CEDAC); 2004.

27. $\mathrm{Xu} \mathrm{XL}$, Li XY, Li H: Socioeconomic impact analysis of SRI in China. China Rural Economics (in Chinese); 2006. English version available: http://scholar.google.com/ scholar_url?hl=en\&q=http://ciifad.cornell.edu/SRI/countries/china/cnciadeng. pdf\&sa=X\&scisig=AAGBfm1 IE2WtonKhHMxx_5aPAnSAuB5QXA\&oi=scholarr.

28. Zheng JG, Zhou L, Chi ZZ, Jiang XL: Agricultural water savings possible through SRI for future water management in Sichuan, China. Chengdu: paper for Crop Research Institute, Sichuan Academy of Agricultural Sciences; 2011. http://www.google.com/\#hl=en\&sclient=psy-ab\&q=zheng+Zhou+Chi+Jiang +Agricultural+Water+Savings+SRI\&oq=zheng+Zhou+Chi+Jiang+Agricultural +Water+Savings+SRI\&gs_l=hp.3. . .126.23924.0.24415.83.66.16.1.2.0.302.7794. 25j35j5j1.66.0.les\%3B..1.0. . 1c.CDwSwJjZcg4\&pbx=1\&bav=on.2,or.r_gc.r_pw. r_qf.\&fp=7e9041a74f73c7f\&biw $=1179 \& b i h=600$. Data from Sichuan Provincial Department of Agriculture.
29. Sinha SK, Talati J: Productivity impacts of the system of rice intensification (SRI): A case study in West Bengal, India. Agric Water Manage 2007, 87:55-60.

30. Satyanaryana A, Thiyagarajan TM, Uphoff N: Opportunities for water saving with higher yield from the system of rice intensification. Irrig Sci 2007 25:99-115

31. Sato $S$, Uphoff N: A review of on-farm evaluations of system of rice intensification methods in Eastern Indonesia. CAB Reviews: Perspectives in Agriculture, Veterinary Science, Nutrition and Natural Resources 2007, 2:54.

32. Ndiri JA, Mati BM, Home PG, Odongo B, Uphoff N: Comparison of water savings of paddy rice under System of Rice Intensification (SRI) growing rice in Mwea, Kenya. Intl J Curr Res Rev 2012, 4:63-73.

33. Nyamai M, Mati BM, Home PG, Odongo B, Wanjugo R, Thuranira EG: Improving crop productivity and water use efficiency in basin rice cultivation in Kenya through SRI. Agric Engin Intl: CIGR Journal 2012, 14:1-9.

34. Styger E, Attaher MA, Guindo H, Ibrahim H, Diaty M, Abba I, Traore M: Application of system of rice intensification practices in the arid environment of the Timbuktu region in Mali. PaddyWater Envir 2011, 9:137-144.

35. Kabir H, Uphoff N: Results of disseminating the System of Rice Intensification with Farmer Field School methods in northern Myanmar Exp Agric 2007, 43:463-476.

36. Uprety R: Economic analysis of System of Rice Intensification (SRI) methods in Morang district of Nepal, main season, 2005. Biratnagar, Nepal: Report from the District Agricultural Development Office, Ministry of Agriculture; 2006.

37. FAO-EU: FAO-EU Food Facility Programme: after One and a Half Years in Nepal. Lalitpur, Nepal: FAO; 2010.

38. Khadka RB: Project Completion Report of EU Food Facility Project. Dhangadhi, Kailali, Nepal: FAYA-Nepal; 2011

39. Turmel MS, Espinosa J, Franco L, Pérez C, Hernández H, González E, Fernández G, Rojas C, Sánchez D, Fernández N, Barrios M, Whalen JK, Turner BL: On-farm evaluation of a low-input rice production system in Panama. Paddy Water Envir 2011, 9:155-161.

40. Namara R, Bossio D, Weligamage $P$, Herath I: The practice and effects of the system of rice intensification (SRI) in Sri Lanka. Qtly J Intl Agric 2008, 47:5-23

41. Dung NT, Minh LN: System of Rice Intensification - Advancing Small Farmers in Mekong Region. Oxfam America: Report prepared by the Plant Protection Department (PPD)/Ministry of Agriculture and Rural Development (MARD) and East Asian Regional Office; 2008.

42. Uphoff N, Anas I, Rupela OP, Thakur AK, Thiyagarajan TM: Learning about positive plant-microbial interactions from the System of Rice Intensification (SRI). Aspects Appl Biol 2009, 98:29-54.

43. Anas I, Rupela OP, Thiyagarajan TM, Uphoff N: A review of studies on SRI effects on beneficial organisms in rice soil rhizospheres. Paddy Water Envir 2011, 9:53-64.

44. Lin XQ, Zhu DF, Lin XJ: Effects of water management and organic fertilization with SRI crop management practices on hybrid rice performance and rhizosphere dynamics. Paddy Water Envir 2011, 9:33-39.

45. Priyanka S, Singh YV, Prasanna R, Shivay YS: Influence of methods of crop establishment and rice varieties on nutrient uptake and soil properties. New Delhi: Research report for Indian Agricultural Research Institute; under review.

46. Prasad A: Going against the grain: The system of rice intensification is now being adapted to wheat - with similar good results. Outlook Business, New Delhi; 2008.

47. ICRISAT-WWF: Sustainable Sugarcane Initiative: improving Sugarcane Cultivation in India - Training Manual. Patancheru, Hyderabad, India: ICRISAT-WWF Dialog Project on Food, Water and Environment, Intl Crop Research Inst for Semi-Arid Tropics; 2008.

48. Diwakar MC, Kumar A, Verma A, Uphoff N: Report on the world-record SRI yield in kharif season 2011. Nalanda district, Bihar state, India. Agric Today, New Delhi; 2012:53-56.

49. Uphoff N: Agroecological implications of the System of Rice Intensification (SRI) in Madagascar. Envir Dev \& Sust 1999, 1:297-313.

50. Cook G, O'Connor T: Rice aplenty in Aceh. Caritas: Spring; 2009. 10-11. www. caritas-europe.org/module/FileLib/RiceaplentyinAceh.pdf.

51. Singh MP: Organic rice cultivation transforming lives of Damoh farmers. The Hindu, Nov. 28, 2011. http://www.thehindu.com/sci-tech/agriculture/ 
article2668286.ece.

52. Lyman J, Lyman J, Rasmei S, Than YK, Chantea L: Rice production in the Family Food Production project. Phnom Penh: Report of LDS Charities; 2007. Posted on SRI website: http://sri.ciifad.cornell.edu/countries/cambodia/camldsrpt07.pdf.

53. McDonald AJ, Hobbs PR, Riha SJ: Does the System of Rice Intensification outperform conventional best management? A synopsis of the empirical record. Field Crops Res 2006, 96:31-36.

54. Uphoff N, Stoop WA, Kassam AH: A critical assessment of a desk study comparing crop production systems: the example of the 'system of rice intensification' vs 'best management practice'. Field Crops Res 2007, 108:109-114.

55. Turnbaugh PJ, Ley RE, Mahady M, Fraser-Liggett CM, Knight R, Gordon J: The Human Microbiome Project. Nature 2007, 449:804-810.

56. Pinton R, Varanini Z, Nannipieri P: The Rhizosphere: Biochemistry and Organic Substances at the Soil-Plant Interface. 2nd edition. Boca Raton, FL: CRC Press; 2007.

57. Mukerij KG, Manoharachary C, Singh J: Microbial Activity in the Rhizosphere. Berlin: Springer; 2006.

58. Chi F, Shen SH, Chang HP, Jing YX, Yanni YG, Dazzo FB: Ascending migration of endophytic rhizobia, from roots to leaves, inside rice plants and assessment of benefits to rice growth physiology. Appl Environ Microbiol 2005, 71:7271-7278.

59. Chi F, Yang PF, Han F, Jing YX, Shen SH: Proteomic analysis of rice seedlings infected by Sinorhizobium meliloti 1021. Proteomics 2010, 10:1861-1874.

60. Mattoo AK, Abdel-Baki A: Crop genetic responses to management: evidence of root-shoot communication. In Biological Approaches to Sustainable Soil Systems. Edited by Uphoff N, Ball A, Fernandes ECM, Herren H, Husson O, Laing M, Palm CA, Pretty JN, Sanchez PA, Sanginga N, Thies JE. Boca Raton, FL: CRC Press; 2006:221-230.

61. Rodriguez RJ, Freeman DC, McArthur ED, Kim YO, Redman RS: Symbiotic regulation of plant growth, development and reproduction. Communic \& Integr Biol 2009, 2:1-3.

62. Uphoff N, Chi F, Dazzo FB, Rodriguez RJ: Soil fertility as a contingent rather than inherent characteristic: Considering the contributions of crop-symbiotic soil biota. In Principles of Sustainable Soil Management in Agroecosystems. Edited by Lal R, Stewart B. Boca Raton, FL: Taylor \& Francis: 2012. in press.

63. Khan Z, Hassanali A, Pickett J: Managing polycropping to enhance soil system productivity: a case study from Africa. In Biological Approaches to Sustainable Soil Systems. Edited by Uphoff N, Ball A, Fernandes ECM, Herren H, Husson O, Laing M, Palm CA, Pretty JN, Sanchez PA, Sanginga N, Thies JE. Boca Raton, FL: CRC Press; 2006:575-586.

64. Uphoff N, Ball A, Fernandes ECM, Herren H, Husson O, Laing M, Palm CA Pretty JN, Sanchez PA, Sanginga N, Thies JE: Biological Approaches to Sustainable Soil Systems. Boca Raton FL: CRC Press; 2006.

65. Laulanié H: Le système de riziculture intensive Malgache. Tropicultura 1993, 11:110-114. reprinted in 2011, 29:3, 183-187, as English translation.

66. Mishra A, Uphoff N: Morphological and physiological responses of rice roots and shoots to varying water regimes and soil microbial densities. Arch Agron Soil Sci 2012, 58:1-27.

67. Husson O: Redox potential (Eh) and $\mathrm{pH}$ as drivers of plant/soil/ microorganism systems: A transdisciplinary overview pointing to integrative opportunities in agronomy. Plant Soil, http://rd.springer.com/ article/10.1007/s11104-012-1429-7.

68. Priyanka S, Singh YV, Prasanna R, Bhatia A, Shivay YS: Pattern of methane emission and water productivity under different methods of rice crop establishment. Paddy Water Envir 2011, 9:1-12.

doi:10.1186/2048-7010-1-18

Cite this article as: Uphoff: Supporting food security in the 21st century through resource-conserving increases in agricultural production. Agriculture \& Food Security 2012 1:18.

\section{Submit your next manuscript to BioMed Central and take full advantage of:}

- Convenient online submission

- Thorough peer review

- No space constraints or color figure charges

- Immediate publication on acceptance

- Inclusion in PubMed, CAS, Scopus and Google Scholar

- Research which is freely available for redistribution

Submit your manuscript at www.biomedcentral.com/submit
Biomed Central 